Research Article

\title{
Out of Asia: An Allopatric Model for the Evolution of the Domestic Dog
}

\author{
Stan Braude ${ }^{1}$ and Justin Gladman ${ }^{2}$ \\ ${ }^{1}$ Biology Department, Washington University, Box 1137, One Brookings Drive, St. Louis, MO 63130, USA \\ ${ }^{2}$ Anthropology Department, Physical Anthropology, City University New York, 535 East 80th Street, New York, NY 10075, USA
}

Correspondence should be addressed to Stan Braude; braude@wustl.edu

Received 29 June 2013; Accepted 28 August 2013

Academic Editors: A. Arslan, J. J. Gros-Louis, and M. Klautau

Copyright (C) 2013 S. Braude and J. Gladman. This is an open access article distributed under the Creative Commons Attribution License, which permits unrestricted use, distribution, and reproduction in any medium, provided the original work is properly cited.

\begin{abstract}
The domestication of the dog has been a ripe area of evolutionary speculation for more than 150 years. A wolf ancestry and probable East Asian origin of domestication are now widely accepted. We offer a new allopatric hypothesis for the domestication of dogs that recognizes the importance of isolation in the speciation of the dog from the wolf. Although sympatric isolation during domestication of many other species would not have been problematic, it has always been difficult to keep dogs from breeding with wild canids. Furthermore, wild canids readily hybridize with one another. This would have made it very difficult for an early domestic dog lineage to diverge from the wolf and to evolve into the morphologically, developmentally, and behaviorally distinct species that we recognize today. Our allopatric model is consistent with two subhypotheses: isolation when tamer scavenger wolves followed humans south and away from hunting populations of wolves or isolation when climate forced humans and tamer scavenger wolves into isolated refugia.
\end{abstract}

\section{Introduction and Background}

The importance of the domestic dog comes not only from the close relationship that humans share with it today, but also because it is the earliest known domesticate, predating any other plant or animal. This unique position as the first domesticate has inspired researchers to ask about the origins of the dog, and the process of its original domestication. The close relationship between the domestic dog (Canis familiaris) and the wolf (Canis lupus) has been recognized and discussed since at least Roman times [1]. Lamark [2] suggested the wolf as the ancestor to the domestic dog, although this hypothesis was dismissed later by Lyell [3]. Darwin [4] suggested multiple origins of domestic dogs from wild canid ancestors in contrast to Wallace's contention of a single origin. Lorenz's [5] assertion that there exist two distinct lineages of domestic dogs, descended from both wolves and jackals, has predominated during much of the last century. He based this dichotomy on physical characteristics including size and muzzle shape. Although dogs can successfully interbreed with both wolves and jackals, the dual origin model has been thoroughly discredited in recent years with new molecular phylogenies of the canids indicating wolf ancestry [6-10].

Lorenz's [11] depiction of the domestication process has, however, persisted. Lorenz's scenario is that domestication began with the adoption of a wild wolf pup as a pet for a child. We certainly have many examples of orphaned wild animals being reared by modern humans. However, most of these events end when adult behavior patterns override any social bond with a human, and we have no evidence that preindustrial people would engage in such behavior. Work by Topál et al. [12] emphasizes that early socialization of wolf pups by humans would not be enough to permanently alter the behaviors of these wild animals, and so the Lorenz model of simple adoption seems inadequate. The popular acceptance of Lorenz's dog domestication scenario may actually result more from the popularity of Jack London's classic tale White Fang [13].

More recently, Belyaev's farm fox breeding experiments have offered valuable insights into the evolution of early domesticates. This work began in Siberia in 1959 and continues to the present [14-16]. Belyaev was able to generate a tame 
breed of foxes by selecting specifically for approachability and lack of fear response to humans, that is, tameness. An unexpected result of this experiment was a suite of morphological characteristics that evolved as correlates of tameness. These included piebald coat color, curled tail, chest and forehead stars, floppy ears, and shortened muzzles.

Many of these morphological characteristics are shared by domestic dogs and other domestic species and may reflect a common developmental mechanism in the evolution of tameness, what Belyaev originally described as a "destabilization effect." By selectively breeding tamer animals, we may actually be selecting for paedomorphy, that is, retention of juvenile characteristics into adult life [16, 17]. Trut suggests that a reorganization of hormonal and neurotransmitter activity linked to changes in the hypothalamus lead to the suite of observed physical and behavioral changes [16]. Crockford [18] hypothesized that results seen in the fox-farm experiment are due, more specifically, to changes in thyroid metabolism and thyroid hormones which are controlled by genes in the hypothalamus. According to this theory, the selection for minor differences in thyroid production results in the difference between wild wolves and domestic dogs. Saetre et al. further support this mechanism with their finding that changes in expression of a limited number of genes in the hypothalamus leads to a suite of correlated characteristics [19].

Regardless of mechanism, Balayev's groundbreaking work showed the importance of selection for tameness in early domesticates. Crockford [20] outlined a canid domestication scenario, similar to Tchernov and Horwitz [21], in which such selection would not require conscious selection by humans. This scenario proposes that wolf scavengers who were less fearful of humans would be more successful as scavengers around human encampments. We also suggest that less aggressive wolves might be forced out of hunting packs and may have been the first animals to fill the scavenger niche. This idea has been less formally described by Morey [22], Clutton-Brock [23] and Manwell and Baker [24] and has come to replace the original scenario of domestication set out by Lorenz [11]. The domestication literature in general has described this process as "unconscious selection" in which humans initiate the process of domestication without intention $[25,26]$. In the case of the dog this unconscious domestication began by tolerating wolf presence closer and closer to their settlements. Crockford [20] explains this protodomestication as the first step in producing a more domesticated animal in which behaviors and physical appearance are already changing. She goes on to define "classic domestication," the second stage of this model, as the direct impact of humans on the animal by artificial selection.

R. Coppinger and L. Coppinger [27] have elaborated on this model in what they term the "village dog" scenario. They share anecdotes of village dogs that still exist in Africa and Asia, but do not distinguish these from feral dogs. These are dogs who survive as scavengers and tolerate humans but are not owned by anyone. At best, they have provided evidence that the village dog ecological niche still exists.

Despite its current popularity, the protodomesticate, or village dog, scenario leaves a major gap in the understanding of how dogs evolved from wolf ancestors. Künz et al. [28] specifically argue that changing a wild animal into a domesticate cannot be accomplished by "unconscious" selection and requires intensive artificial selection over many generations. This is supported by the fact that wolves who scavenge around human settlements today are no tamer than other wolf populations [29]. Even wolf dog hybrids are known for extremely high levels of aggression and unpredictability towards humans [30,31]. Possibly a larger problem with this protodomesticate model of the dog domestication is that it relies on human settlements, or villages, for this "unconscious selection" to occur. With archeological finds of domestic dog remains pushing the domestication event back before 16,000 years ago $[32,33]$, the transition between huntergatherer people and agriculturalists comes into play. The idea of hunter-gatherer domestication was proposed by Davis and Valla [34] with the discovery of an early (12,000-year-old) domestic dog in a Natufian site. If the time of domestication is found to occur before agriculturalists formed permanent settlements, the protodomestication or village dog scenario must be reexamined due to its dependence on human sedentism.

\section{The Problem of Isolation}

What all of these domestication scenarios are also missing is isolation of the domesticating lineage from wild populations (Figure 1(a)). Coppinger and Schneider [35] specifically note this problem but suggest that the original scavenger village wolf/dogs would separate themselves from the surrounding hunter wolf population. This seems unlikely considering how frequently and easily canids interbreed [18,36-38].

Although humans may have been able to physically isolate ungulates from their wild relatives with physical barriers (fences) and restraints (ropes), tamed wolves would be far more difficult to contain [12]. Clutton-Brock and Jewell [39] note such problems with domestic/feral dingoes. Furthermore, there is no evidence that prehistoric dogs were primarily kept inside houses. This seems unlikely until recent times. In fact, the role of dogs as guards depends on them living outside, and their role as hunting companion often depends on them running free. These are thought to have been primary jobs until they were recently transformed into companion animals [39]. Thus, repeated interbreeding with the wild population would have prevented speciation of domestic dogs from the surrounding wolf population.

\section{The Allopatric Model of Dog Evolution}

Current models of the evolution of the domestic dog from a wolf ancestor cannot explain how the domestic population was isolated from introgression of wolf genes in the early stages of domestication and why there should be an East Asian origin.

An Asian origin for domestic dogs was suggested by Olsen $[40,41]$ based on specific morphological similarities shared between the domestic dog and the Chinese wolf ( $C$. lupus chanco), also known as the Tibetan wolf (C. lupus laniger). More recent evidence for an East Asian origin 


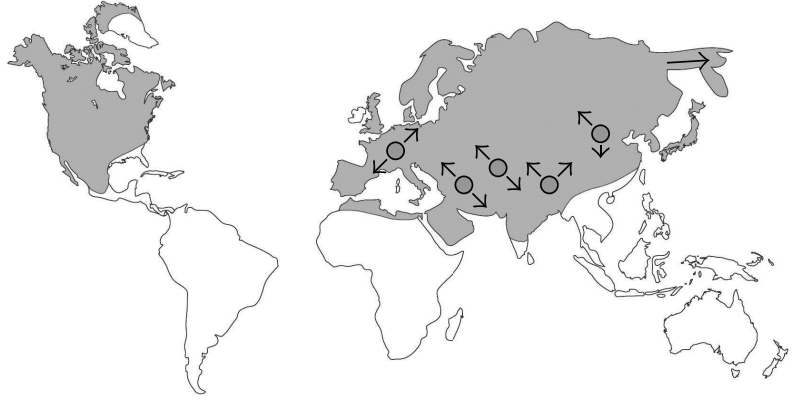

(a)
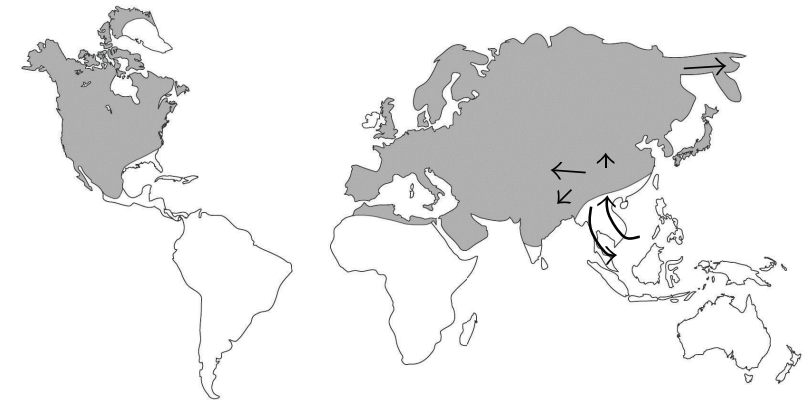

(b)
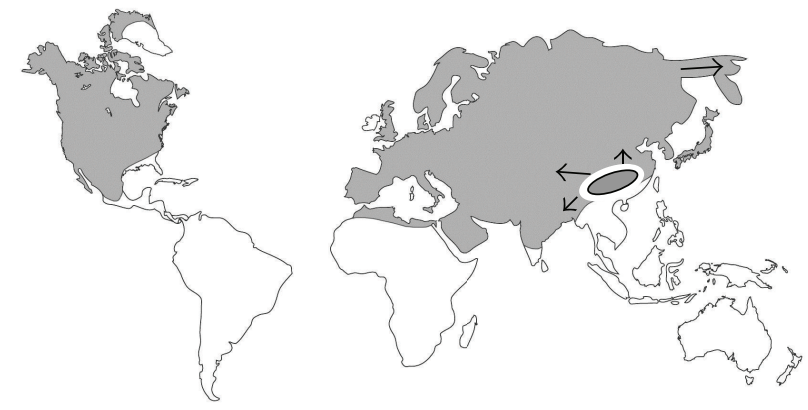

(c)

FIgURE 1: The historic distribution of wolves from arctic through subtropical latitudes is represented in grey. The various sympatric models (a) of domestic dog evolution propose that dogs evolved from within wolf populations. Some models predict multiple origins, and others do not specify the number of origins. Arrows represent spread of dogs once domestication has occurred. The Indonesian allopatric model (b) proposes that wolf scavenger populations were able to follow humans onto the Indonesian plateau where they were isolated from hunting populations of wolves which do not extend into tropical habitats. Arrows represent movement onto the Indonesian plateau and subsequent spread across Eurasia. The refugium allopatric model (c) proposes that some human populations and wolf scavenger populations were separated from hunting wolf populations on patches of habitat which were isolated during the Pleistocene. Arrows represent spread of dogs after domestication within the refugia.

for dog lineages based on molecular phylogenies $[8,9,42$, 43] begs the question of what features of human or wolf communities in East Asia would have driven dog divergence there, rather than in other parts of the globe. We know that wolf populations coexisted with humans across Eurasia and North America down into the subtropics [44]. Wolves never successfully expanded, however, into tropical regions.

Although sympatric speciation does occur [45-47], known examples require unusual genetic, ecological, or historic events. Sympatric speciation of dogs from wolves seems unlikely considering how easily canids interbreed even today [20, 36-38]. However, many authors, including Crockford [18], argue convincingly that dogs evolved from a subgroup of wolves that were more tolerant of human presence and were attracted to the perimeters of human settlement as scavengers. We propose that these scavenger populations must have become isolated from other populations of wolves. Either they followed humans who were moving south into habitat which is unsuitable for hunting wolves, or pockets of humans and scavenger wolves in the subtropics became isolated by climate change ca. $15 \mathrm{k}$ to $20 \mathrm{k}$ years ago. It is important to note that both of these possible isolation events take into account the changing climate at the end of the Last Glacial Maximum some 18 kya. This important variable has been overlooked in current models of canid domestication, and we argue that the timing of this dramatic change is not a random coincidence.

The East Asian origin for domestication [8, 40] at first does not appear to allow for isolation from grey wolf populations since grey wolves have historically been distributed throughout Asia. However, until 10-12 thousand years ago, tropical/equatorial Borneo and Indonesia were contiguous with South Asia a result of the recent ice age [48]. Hence, scavenger wolf populations of East Asian origin could have followed humans south into the Indonesian plateau and become isolated from their grey wolf relatives who occupied a hunter (rather than scavenger) niche and could not follow (Figure 1(b)). Once geographically isolated, any attempts at domestication would not have been counteracted by introgression with wild wolf populations.

An alternative allopatric scenario is that climate change might have created pockets of habitat suitable for humans and their associated scavenger wolves which were isolated from the larger hunting wolf population (Figure 1(c)). Such pockets could have formed in Asia during the Last Glacial Maximum and driven the evolution of the domestic dog by forcing scavenger wolves and their human hosts into isolated refugia. These same climatic events have been thought to affect the evolutionary history of other canids including the red fox [49], brown bear species [50, 51], and even some wolf 
populations [52] in other parts of the world. Frati et al. [49] provide a valuable account of how red fox populations (Vulpes vulpes) may have been forced into population "pockets" during times of glacial maximum with subsequent radiations in times of warming. Changes in their forest habitat [53] or in the distribution of their large prey species [54] may have caused similar refugia pockets to form around humans who provide an alternate source of food for scavenger wolf populations.

Remigration north out of the Indonesian plateau, or the recession of harsh climatic pressures and subsequent population expansion, would have placed the founding dog populations in East Asia. Dogs would have been traded and spread quickly out of Asia. Because canids interbreed with such facility, it is not surprising that modern phylogenies show occasional introgression of wolf genes into dog populations and dog genes into wolf populations. This trail of introgressions is debated in the literature but receives strong support by Tsuda et al. [36]. However, once dogs were domesticated in isolation from wolves, occasional hybridization would not have caused disappearance of this valuable domestic species. Estimates of 14-20 thousand years bp for the first appearance of domestic dogs in Eurasian and North American human archaeological sites are consistent with this model.

There remains the question of why the first scavenger wolves would approach human camps, especially at a time when humans were formidable hunters. The village dog model suggests that the scavengers would fill a niche around human settlements, but we now know that domestication occurred before humans became sedentary. One possible solution is that humans and wolves became facultative hunting partners, and this opened the way for further tolerance. Alternatively, we offer the possibility that low ranking, and less aggressive, wolves might have been forced out of packs of hunting wolves and forced to scavenge to survive. Their lack of success in an aggressive hierarchy might have also predisposed this subpopulation of wolves to be more tolerant of humans and less threatening.

An additional gap remains in our understanding of why the first pups would be reared by humans. While Lorenz suggested that these first domesticates would already be pets, we suggest that hunter-gatherer humans would have reared pups as food. This is consistent with the initial domestication of donkeys, horses, and oxen, all of which were initially kept as a readily available food source and only later used for transportation or other work. Dogs have long been a common item in human diets in Asia [55], the Pacific Islands [56, 57], and North America [58-60] with particular importance in cold winter months [60]. This step in the domestication scenario bridges the gap between scavenger wolves on the outer limits of human camps and a domestic species reared by humans. Selection for approachability and tameness (not because humans wanted pets but because these characteristics would make dogs a more manageable food resource) suggested by Belyaev's fox farm experiments could have rapidly produced a useful domestic guard and hunting companion which would socially bond to humans but not retain the dangerous and unpredictable characteristics of tamed wolves.

\section{Predictions of Our Model}

The model we have proposed differs in both the reason for domestication and the mechanism of domestication for dogs (Table 1). In addition to the evidence we have reviewed, certain predictions follow from our model. First, our model suggests that skulls of wolf/dog intermediates should be found in either East Asia (refugia version of our model) or further south in the Indonesian archipelago (migration version of our model). The southern migration version of our model also predicts that northern species of commensal rodents and other species that scavenged around human camps will be found along with wolf/dog bones in human archaeological sites along the Indonesian archipelago. Both versions of our model predict that the earliest canid bones found in human archaeological sites in East Asia will show evidence of human consumption of the animals. In addition, our models predict that there should be a genetic signature of a bottleneck event in the origin of domestic dogs, followed by repeated introgression of wolf genes. Finally, our model predicts that the earliest domestic dogs will predate the earliest human settlements, hence excluding the village dog scenario.

\section{Conclusions}

The domestication of the dog is an amazing puzzle because of the extremely close relationship we share with dogs in spite of the fact that they are such potentially dangerous predators. With such strong cultural connections to the dog, the literature on its domestication often seems heavy with the biases of the present relationship between humans and dogs. Existing hypothesized domestication scenarios all fail to adequately explain how this species became reproductively isolated from wolves. Sympatric models of dog domestication do not account for the obstacle of canid promiscuity in the domestication process nor do they explain how the wolf shifts from the outskirts of human encampments to the doorsteps of human domiciles. These models also ignore the quickly changing environment at the end of the Last Glacial Maximum and how this plays into the origins of the dog. Only the allopatric model of dog domestication can account for these problems.

The allopatric model focuses on isolation of tamer, scavenger wolf populations from wild hunter wolf populations through shifting human settlements or through isolation due to shifting climate. The exploitation of the Indonesian plateau by migrating humans would produce this isolation by drawing the scavenger wolf population away from its surrounding hunter wolves so that domestic lineages would not be repeatedly diluted by wild stock. Likewise, shifting climates at the end of the Pleistocene created environmental refugia in which scavenger wolves and humans may have been together isolated from the larger hunter population of wolves. Both situations are congruent with recent genetic evidence on the geographic and temporal origin of the domestic 
TABLE 1: Comparison of models of dog domestication.

\begin{tabular}{|c|c|c|c|}
\hline Model & White fang model & Village dog model & Allopatric model \\
\hline Reference & $\begin{array}{l}\text { London (1905) [13] } \\
\text { Lorenz (1952) [5] }\end{array}$ & $\begin{array}{l}\text { Clutton-Brock and Jewell (1993) } \\
\text { [39] } \\
\text { Morey (1994) [22] } \\
\text { Coppinger and Schneider (1995) } \\
\text { [35] } \\
\text { Crockford (2000) [20] }\end{array}$ & Braude and Gladman, herein \\
\hline First step & Adoption of wolf pup & $\begin{array}{l}\text { Wolves scavenge } \\
\text { around human } \\
\text { settlements }\end{array}$ & $\begin{array}{l}\text { Wolves follow humans } \\
\text { and scavenge }\end{array}$ \\
\hline Selection & Human selection for tameness & $\begin{array}{l}\text { Ecological selection for tolerance of } \\
\text { humans }\end{array}$ & $\begin{array}{l}\text { Ecological selection for tolerance of } \\
\text { humans }\end{array}$ \\
\hline Speciation process & $\begin{array}{l}\text { Human imposed } \\
\text { Separation of } \\
\text { domestic line } \\
\text { from wild population }\end{array}$ & $\begin{array}{l}\text { Sympatric } \\
\text { despite local } \\
\text { wild hunting } \\
\text { population }\end{array}$ & $\begin{array}{l}\text { Allopatric separation } \\
\text { of tolerant scavenger population from } \\
\text { wild hunting population }\end{array}$ \\
\hline Location of origin & $\begin{array}{l}\text { Eurasia, Africa, } \\
\text { and North America }\end{array}$ & Unspecified & East Asia \\
\hline $\begin{array}{l}\text { Reason for initial } \\
\text { domestication }\end{array}$ & $\begin{array}{l}\text { Pet for woman } \\
\text { or child }\end{array}$ & $\begin{array}{l}\text { Jump from scavenger to hunting } \\
\text { companion and guard }\end{array}$ & Source of meat \\
\hline
\end{tabular}

dog and fit with previous morphological conclusions about which wolf subspecies the dog came from.

We have also offered a new explanation of how tamed wolf populations made it into and around human households. Recognizing that dogs may have been first used as food before they were valued as guards and hunting companions aligns the dog with most other domesticates, and is strongly supported in historic and recent ethnographic studies. This idea of the domestic dog being used as a staple food resource is an example of how our current biases on the taboos of dog in Western diet affects the way we examine the past association of humans and their dogs. This also allows for the final stages of domestication to occur with dogs becoming totally dependent on humans.

As data on canid phylogeny and archaeology continue to accumulate, we will be better able to evaluate the merits of the scenarios hypothesized here. Nonetheless, we have offered resolution to a number of gaps in the hypothesized origins of the domestic dog. Hopefully our model will bring us closer to understanding how the amazing relationship between humans and dogs began.

\section{Acknowledgments}

The authors would like to thank the colleagues who generously read and commented on earlier versions of this paper, especially Nancy Berg, Fiona Marshall, Zuleyma TangMartinez, George Taylor, Karen Norberg, and Bobbi Low.

\section{References}

[1] L. M. Wendt, Dogs: A Historical Journey, Macmillan, New York, NY, USA, 1996.

[2] J. B. Lamark, Zoological Philosophy: An Exposition with Regard to the Natural History of Animals, vol. 1, Dentu, Paris, France, 1809.
[3] C. Lyell, Principles of Geology, vol. 2, J. Murray, London, UK, 1835.

[4] C. Darwin, On the Origin of Spcecies, John Murray, London, UK, 1859.

[5] K. Lorenz, King Solomon's Ring, Harper \& Row, New York, NY, USA, 1952.

[6] C. Vilà, P. Savolainen, J. E. Maldonado et al., "Multiple and ancient origins of the domestic dog," Science, vol. 276, no. 5319, pp. 1687-1689, 1997.

[7] J. A. Leonard, R. K. Wayne, J. Wheeler, R. Valadez, S. Guillén, and C. Vilà, "Ancient DNA evidence for old world origin of New World dogs," Science, vol. 298, no. 5598, pp. 1613-1616, 2002.

[8] P. Savolainen, Y.-P. Zhang, J. Luo, J. Lundeberg, and T. Leitner, "Genetic evidence for an East Asian origin of domestic dogs," Science, vol. 298, no. 5598, pp. 1610-1613, 2002.

[9] E. A. Ostrander and R. K. Wayne, "The canine genome," Genome Research, vol. 15, no. 12, pp. 1706-1716, 2005.

[10] K. Lindblad-Toh, C. M. Wade, T. S. Mikkelsen et al., "Genome sequence, comparative analysis and haplotype structure of the domestic dog," Nature, vol. 438, no. 7069, pp. 803-819, 2005.

[11] K. Lorenz, Man Meets Dog, Kodansha International, New York, NY, USA, 1953.

[12] J. Topál, M. Gácsi, Á. Miklósi, Z. Virányi, E. Kubinyi, and V. Csányi, "Attachment to humans: a comparative study on handreared wolves and differently socialized dog puppies," Animal Behaviour, vol. 70, no. 6, pp. 1367-1375, 2005.

[13] J. London, White Fang, Penguin, London, UK, 1905.

[14] D. K. Belyaev, "Destabilizing selection as a factor in domestication," The Journal of Heredity, vol. 70, no. 5, pp. 301-308, 1979.

[15] L. N. Trut, "Early canid domestication: the farm-fox experiment: foxes bred for tamability in a 40-year experiment exhibit remarkable transformations that suggest an interplay between behavioral genetics and development," American Scientist, vol. 87, no. 2, pp. 160-169, 1999.

[16] L. N. Trut, "Experimental studies of early canid domestication," in The Genetics of the Dog, CABI Publishing, New York, NY, USA, 2001. 
[17] H. Hemmer, Domestication: The Decline of Environmental Appreciation, Cambridge University Press, Cambridge, Mass, USA, 1990.

[18] S. J. Crockford, "Dog evolution: a role for thyroid hormone physiology in domestication changes," in Dogs through Time: An Archaeological Perspective, S. J. Crockford, Ed., BAR International Series no. 889, Archaeopress, Oxford, UK, 2000.

[19] P. Saetre, J. Lindberg, J. A. Leonard et al., "From wild wolf to domestic dog: gene expression changes in the brain," Molecular Brain Research, vol. 126, no. 2, pp. 198-206, 2004.

[20] S. J. Crockford, "A commentary on dog evolution: regional variation, breed development and hybridization with wolves," in Dogs through Time: An Archaeological Perspective, S. J. Crockford, Ed., BAR International Series no. 889, Archaeopress, Oxford, UK, 2000.

[21] E. Tchernov and L. K. Horwitz, "Body size diminution under domestication: unconscious selection in primeval domesticates," Journal of Anthropological Archaeology, vol. 10, no. 1, pp. 54-75, 1991.

[22] D. F. Morey, "The early evolution of the domestic dog," American Scientist, vol. 82, no. 4, pp. 336-347, 1994.

[23] J. Clutton-Brock, "Origins of the dog: domestication and early history," in The Domestic Dog: Its Evolution, Behaviour and Interactions with People, J. Serpell, Ed., Cambridge University Press, New York, NY, USA, 1995.

[24] C. Manwell and C. Baker, "Domestication of the dog: hunter, food, bed-warmer, or emotional object?" Zeitschrift für Tierzüchtung und Züchtungsbiologie, vol. 101, no. 1-5, pp. 241256, 1984.

[25] D. Zohary, E. Tchernov, and L. K. Horwitz, "The role of unconscious selection in the domestication of sheep and goats," Journal of Zoology, vol. 245, no. 2, pp. 129-135, 1998.

[26] D. Rindos, The Origins of Agriculture: An Evolutionary Approach, Academic Press, New York, NY, USA, 1984.

[27] R. Coppinger and L. Coppinger, Dogs, Scribner, New York, NY, USA, 2001.

[28] C. Künzl, S. Kaiser, E. Meier, and N. Sachser, "Is a wild mammal kept and reared in captivity still a wild animal?" Hormones and Behavior, vol. 43, no. 1, pp. 187-196, 2003.

[29] M. E. McNay, "Wolf-human interactions in Alaska and Canada: a review of the case history," Wildlife Society Bulletin, vol. 30, no. 3, pp. 831-843, 2002.

[30] J. S. Gloyd, "Wolf hybrids—a biological time bomb?" Journal of the American Veterinary Medical Association, vol. 201, no. 3, pp. 381-382, 1992.

[31] J. Hope, "Wolves and wolf hybrids as pets are big business-but a bad idea," Smithsonian, vol. 25, pp. 34-42, 1994.

[32] M. V. Sablin and G. A. Khlopachev, "The earliest ice age dogs: evidence from Eliseevichi I," Current Anthropology, vol. 43, no. 5, pp. 795-799, 2002.

[33] R. D. E. MacPhee, A. N. Tikhonov, D. Mol et al., "Radiocarbon chronologies and extinction dynamics of the late Quaternary mammalian megafauna of the Taimyr Peninsula, Russian Federation," Journal of Archaeological Science, vol. 29, no. 9, pp. 10171042, 2002.

[34] J. M. Davis and F. R. Valla, "Evidence for domestication of the dog 12,000 years ago in the Natufian of Israel," Nature, vol. 276, no. 5688 , pp. 608-610, 1978.

[35] R. Coppinger and R. Schneider, "Evolution of working dogs," in The Domestic Dog, J. Serpel, Ed., Cambridge Press, Cambridge, Mass, USA, 1995.
[36] K. Tsuda, Y. Kikkawa, H. Yonekawa, and Y. Tanabe, "Extensive interbreeding occurred among multiple matriarchal ancestors during the domestication of dogs: evidence from inter- and intraspecies polymorphisms in the D-loop region of mitochondrial DNA between dogs and wolves," Genes and Genetic Systems, vol. 72, no. 4, pp. 229-238, 1997.

[37] J. R. Adams, J. A. Leonard, and L. P. Waits, "Widespread occurrence of a domestic dog mitochondrial DNA haplotype in southeastern US coyotes," Molecular Ecology, vol. 12, no. 2, pp. 541-546, 2003.

[38] P. Ciucci, V. Lucchini, L. Boitani, and E. Randi, "Dewclaws in wolves as evidence of admixed ancestry with dogs," Canadian Journal of Zoology, vol. 81, no. 12, pp. 2077-2081, 2003.

[39] J. Clutton-Brock and P. Jewell, "Origin and domestication of the dog," in Miller's Anatomy of the Dog, W.B. Saunders, New York, NY, USA, 3rd edition, 1993.

[40] S. J. Olsen and J. W. Olsen, "The Chinese wolf, ancestor of new world dogs," Science, vol. 197, no. 4303, pp. 533-535, 1977.

[41] S. J. Olsen, Origins of the Domestic Dog: The Fossil Record, University of Arizona Press, Tuscon, Ariz, USA, 1985.

[42] P. Savolainen, T. Leitner, A. N. Wilton, E. Matisoo-Smith, and J. Lundeberg, "A detailed picture of the origin of the Australian dingo, obtained from the study of mitochondrial DNA," Proceedings of the National Academy of Sciences of the United States of America, vol. 101, no. 33, pp. 12387-12390, 2004.

[43] D. K. Sharma, J. E. Maldonado, Y. V. Jhala, and R. C. Fleischer, "Ancient wolf lineages in India," Proceedings of the Royal Society $B$, vol. 271, no. 3, pp. 1-4, 2004.

[44] R. M. Nowak, "Another look at wolf taxonomy," in Ecology and Conservation of Wolves in a Changing World, L. N. Carbyn, S. H. Fritts, and D. R. Seip, Eds., Canadian Circumpolar Institute, Edmonton, Canada, 1995.

[45] I. Kornfield and P. F. Smith, "African cichlid fishes: model systems for evolutionary biology," Annual Review of Ecology and Systematics, vol. 31, pp. 163-196, 2000.

[46] S. H. Berlocher and J. L. Feder, "Sympatric speciation in phytophagous insects: moving beyond controversy?" Annual Review of Entomology, vol. 47, pp. 773-815, 2002.

[47] D. I. Bolnick, "Waiting for sympatric speciation," Evolution, vol. 58, no. 4, pp. 895-899, 2004.

[48] P. Bellwood, Prehistory of the Indo-Malaysian Archipelago, Australian National University Press, Canberra, Australia, 1985.

[49] F. Frati, G. B. Hartl, S. Lovari, M. Delibes, and G. Markov, "Quaternary radiation and genetic structure of the red fox Vulpes vulpes in the Mediterranean Basin, as revealed by allozymes and mitochondrial DNA," Journal of Zoology, vol. 245, no. 1, pp. 43-51, 1998.

[50] I. Barnes, P. Matheus, B. Shapiro, D. Jensen, and A. Cooper, "Dynamics of pleistocene population extinctions in Beringian brown bears," Science, vol. 295, no. 5563, pp. 2267-2270, 2002.

[51] J. A. Leonard, R. K. Wayne, and A. Cooper, "Population genetics of Ice Age brown bears," Proceedings of the National Academy of Sciences of the United States of America, vol. 97, no. 4, pp. 16511654, 2000.

[52] V. Lucchini, A. Galov, and E. Randi, "Evidence of genetic distinction and long-term population decline in wolves (Canis lupus) in the Italian Apennines," Molecular Ecology, vol. 13, no. 3, pp. 523-536, 2004.

[53] C. Vilà, I. R. Amorim, J. A. Leonard et al., "Mitochondrial DNA phylogeography and population history of the grey wolf Canis lupus," Molecular Ecology, vol. 8, no. 12, pp. 2089-2103, 1999. 
[54] L. E. Carmichael, J. A. Nagy, N. C. Larter, and C. Strobeck, "Prey specialization may influence patterns of gene flow in wolves of the Canadian Northwest," Molecular Ecology, vol. 10, no. 12, pp. 2787-2798, 2001.

[55] J. Cui and Z. Q. Wang, "Outbreaks of human trichinellosis caused by consumption of dog meat in China," Parasite, vol. 8, no. 2, pp. S74-S77, 2001.

[56] M. Titcomb, Dog and Man in the Ancient Pacific with Special Attention to Hawaii, Bishop Museum Special Publication no. 59, Star-Bulletin, Honolulu, Hawaii, USA, 1969.

[57] L. K. Corbett, "Morphological comparisons of Australian and Thai dingoes: a reappraisal of dingo status, distributiona nd ancestry," Proceedings of the Ecological Society of Australia, vol. 13, pp. 277-291, 1985.

[58] M. Lantis, "Changes in the Alaskan Eskimo relation of man to dog and their effect on two human diseases," Arctic Anthropology, vol. 17, pp. 2-24, 1980.

[59] W. K. Powers and M. N. Powers, "Putting on the dog," Natural History, vol. 95, pp. 6-16, 1986.

[60] L. M. Snyder, "Barking mutton: ethnohistoric, ethnographic, archaeological, and nutritional evidence pertaining to dogs as a Native American food resource on the Plains," in Beamers, Bobwhites, and Blue-Points, Tributes to the Career of Paul W. Parmalee, J. R. Purdue, W. E. Klippel, and B. W. Styles, Eds., vol. 23 of Illinois State Museum Scientific Papers, Illinois State Museum, Springfield, Ill, USA, 1991. 

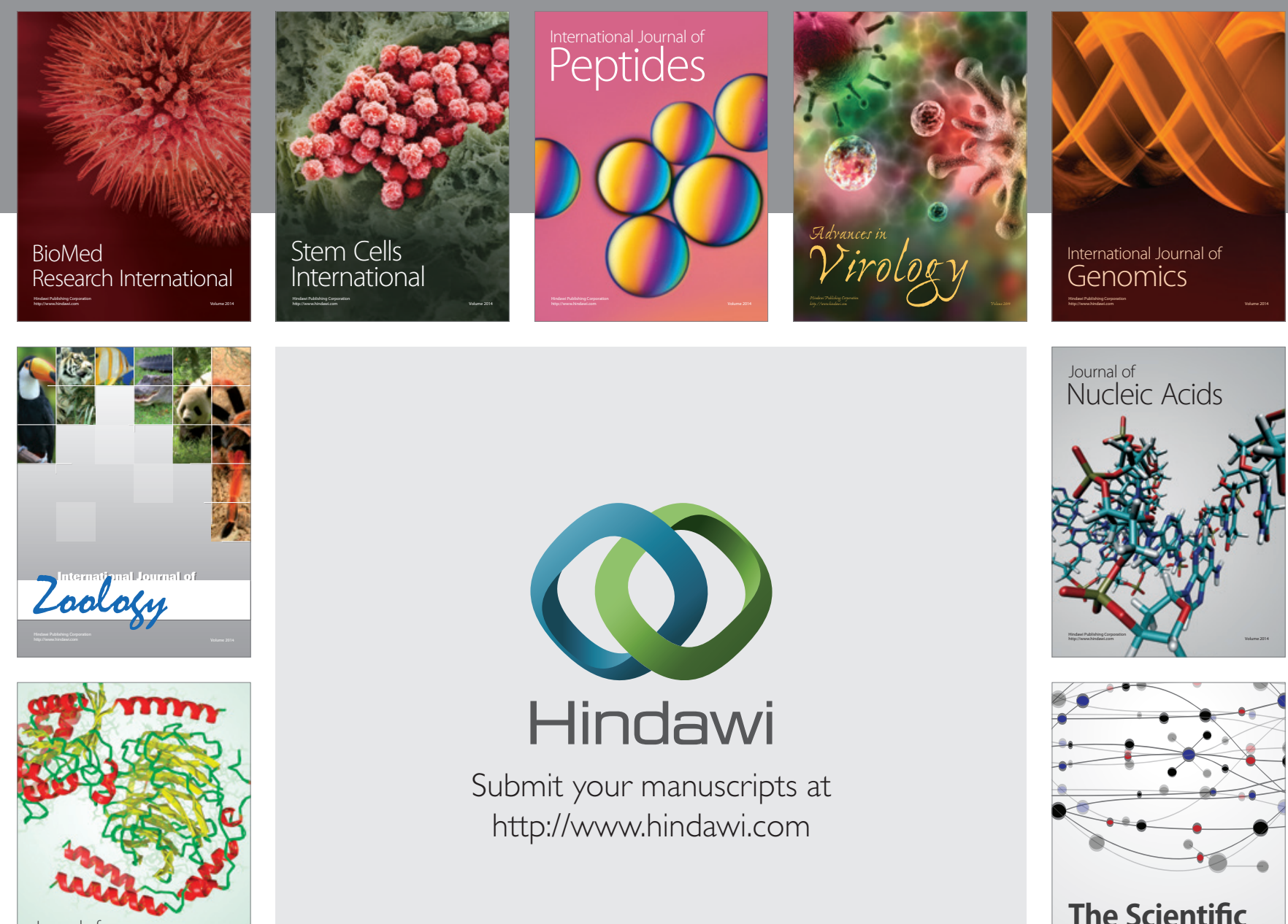

Submit your manuscripts at

http://www.hindawi.com

Journal of
Signal Transduction
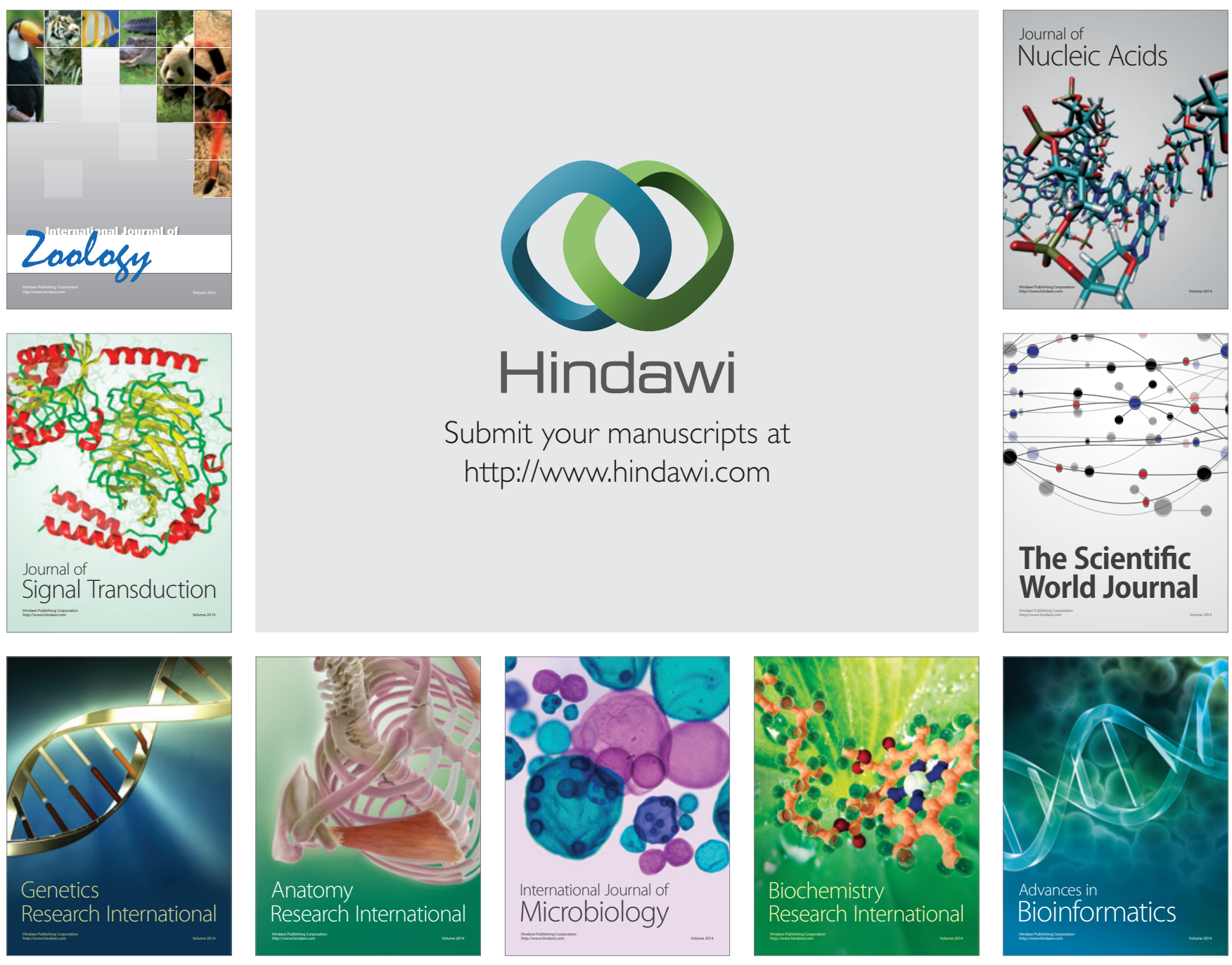

The Scientific World Journal
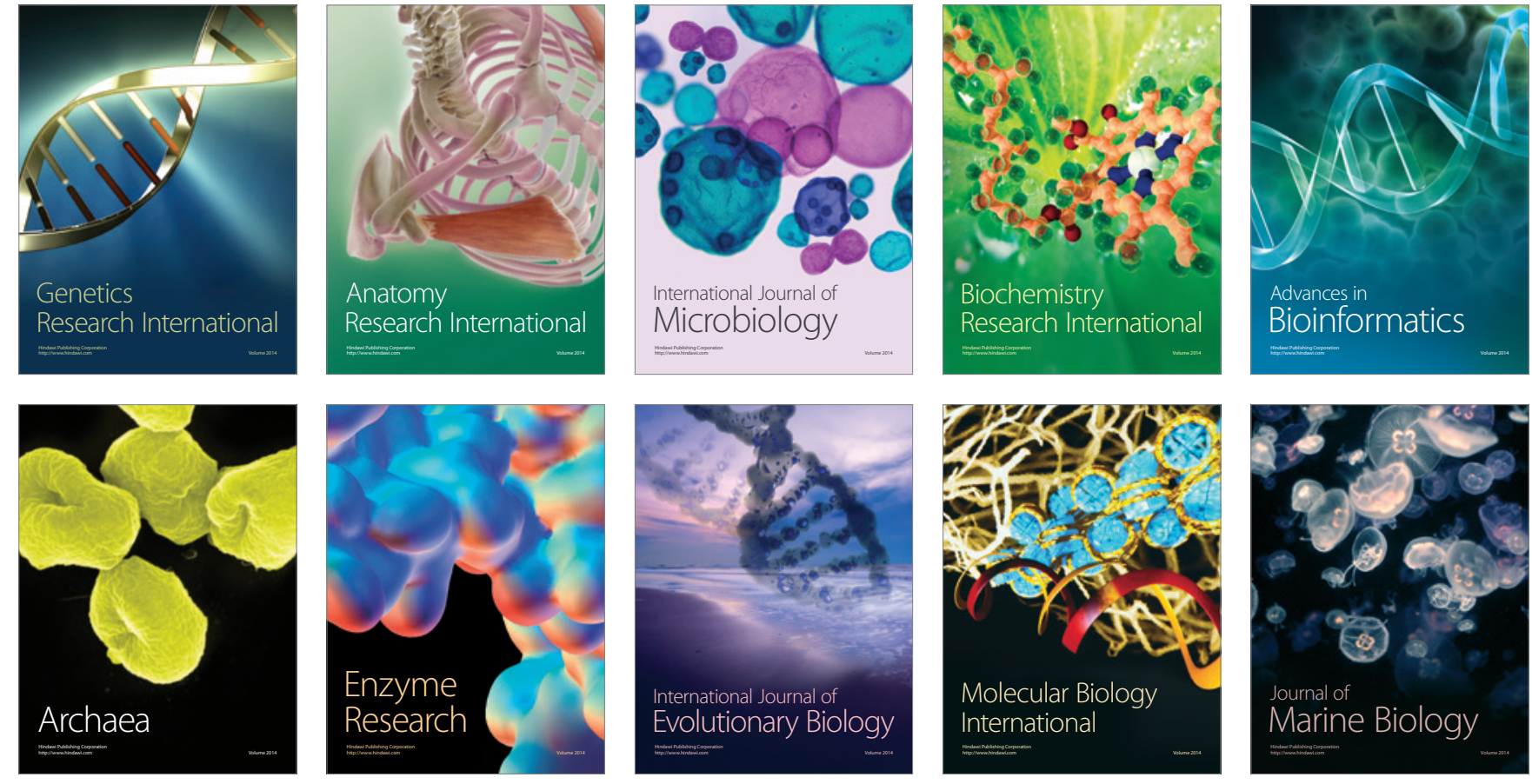